\title{
Things as Co-Ethnographers: Implications of a Thing Perspective for Design and Anthropology
}

\author{
Author(s) \\ Giaccardi, Elisa; Speed, Chris; Cila, Nazli; Caldwell, Melissa L. \\ Publication date \\ 2016 \\ Document Version \\ Submitted manuscript \\ Published in \\ Design anthropological futures
}

Link to publication

\section{Citation for published version (APA):}

Giaccardi, E., Speed, C., Cila, N., \& Caldwell, M. L. (2016). Things as Co-Ethnographers: Implications of a Thing Perspective for Design and Anthropology. In R. C. Smith, K. Tang Vangkilde, M. Gislev

Kjærsgaard, T. Otto, J. Halse, \& T. Binder (Eds.), Design

anthropological futures Bloomsbury Academic.

It is not permitted to download or to forward/distribute the text or part of it without the consent of the author(s) and/or copyright holder(s), other than for strictly personal, individual use, unless the work is under an open content license (like Creative Commons).

If you believe that digital publication of certain material infringes any of your rights or (privacy) interests,

please let the Library know, stating your reasons. In case of a legitimate complaint, the Library will make the material inaccessible and/or remove it from the website. Please contact the library:

https://www.amsterdamuas.com/library/contact/questions, or send a letter to: University Library (Library of the University of Amsterdam and Amsterdam University of Applied Sciences), Secretariat, Singel 425, 1012 WP Amsterdam, The Netherlands. You will be contacted as soon as possible. 


\section{Things As Co-ethnographers: Implications of a Thing Perspective for Design and Anthropology}

Chapter $\cdot$ September 2016

CITATIONS

3

4 authors, including:

\section{Elisa Giaccardi}

Delft University of Technology

61 PUBLICATIONS 1,080 CITATIONS

SEE PROFILE
READS

86

Some of the authors of this publication are also working on these related projects: 
To appear in R.C. Smith et al. (eds) (2016) Design Anthropology Futures, London: Bloomsbury.

\section{Things as Co-ethnographers: Implications of a Thing Perspective for Design and Anthropology}

Elisa Giaccardi | Delft University of Technology, Delft, Netherlands

Chris Speed | University of Edinburgh, Edinburgh, UK

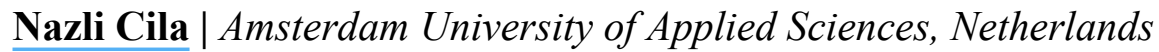

Melissa L. Caldwell | University of California, Santa Cruz, USA

As humans, we have complex and intertwined relationships with the objects around us. We shape objects; and objects shape and transform our practices and us in return. Acknowledging this ongoing interaction among people and objects calls for approaches in both design and anthropology that give both parties an equal role.

In the current design research agenda however, humans take a central place in methodology with the tools and methods of user-centered design (cf. Greenbaum \& Kyng 1991) and participatory design (cf. Schuler \& Namioka 1993). This focus on the human is essential for investigating the subjective experience of everyday practice, but assumes that possibilities for creativity and innovation are bounded only to human imagination and capabilities. In this arrangement, the relationship between humans and objects is unidirectional: humans are actants that 'make' objects with a clear encoded function.

But what happens if we shift the focus to objects that break down, get dirty, contest their original function and even begin to perform autonomously? What if we try to understand the world from the perspective of a 'thing' that is situated within relationships with other entities and that has the potential to influence the existence of those other entities? For instance, what would the world look like from the perspective of a kettle, and how might a kettle inspire the existence of other entities? What kind of anthropological insights and design opportunities would this approach provide? 
Our argument in this chapter is that a thing perspective can bring unique insights about the relationships among objects and human practices, and ultimately present new ways of framing and solving problems collaboratively with things, which have different skills and purposes than humans ${ }^{\mathrm{ii}}$.

Drawing from materials gathered during the Thing Tank research project, a collaborative platform for design inquiry in the Internet of Things, this chapter examines the potential that a thing perspective holds for design and anthropology, and for design anthropology specifically, as it challenges anthropocentric assumptions about the world and opens up new ways of understanding objects, people and use practices.

In particular, the chapter is concerned with what a methodological and analytical focus on things as actants, and perhaps even social actors, may reveal about the types of social relations and power dynamics that inhere among things, and among things and people. Based on these considerations, we argue that things may serve as co-ethnographers. Equipped with software and sensors, they can have access to fields, data and perspectives that we as human ethnographers do not, and therefore may help us 'see' what was previously invisible to humans.

\section{Thing Tank as critical inquiry in the Internet of Things}

Thing Tank is an Internet of Things ${ }^{\mathrm{iii}}$ (IoT) research project that uses a combination of field studies, object instrumentation and machine learning to 'listen' to what things have to tell about their use, reuse and deviant repurposing. It uses this data to inspire idea generation, fabrication, rapid prototyping and business development generation. ${ }^{\text {iv }}$

In the past many Internet of Things projects have used the network connection of physical objects to identify cost saving and process efficiencies (e.g., vehicle manufacturers), to track goods within large networks (e.g., logistics companies), or to monitor the health and safety of systems (e.g., aircraft manufacturers) within a streamlined process of production. But as objects connected to the Internet become more common and able to collect massive amounts of data, they may begin to reveal patterns that were previously invisible to humans, and contest what we usually take for granted. 
Within a user-centered design approach, the role of objects is usually to support people to imagine, discuss, and shape future practices at project time (Donovan \& Gunn 2012). By extension, design becomes a kind of stabilizing process through which future practice(s) are imagined and realized (122). In Thing Tank instead, we take a design orientation according to which we consider every situation of use as a potential design situation. We approach the Internet of Things as an infrastructure that has the potential to support ways of understanding and designing that take place after, with and beyond the design work at project time (Giaccardi 2005; Ehn 2008; Binder et al. 2011; Redström 2012).

The Thing Tank approach requires anthropological engagement. ${ }^{\mathrm{v}}$ It assumes to 'spend time' with objects and 'work together with' them in order to exorcise and manifest forms of practice they partake in, which may have emerged 'after design'. As argued by Gunn \& Donovan (2012), engagement in design approaches sensitive to anthropological concerns requires developing capacities to offer people different ways of understanding what they know and do (6). These different ways of understanding allow for reframing and reconfiguring social and material relations, and are inherently performative and transformative. By 'listening' to objects for an extended period of time, and reflecting on what we usually take for granted, we open up and articulate design spaces that were previously unconceivable. To understand the humans we are asking the 'thing'.

In this chapter, we reflect on the Thing Tank pilot study to develop a conceptual framing about the role that things may play as co-ethnographers in both design and anthropology. As co-ethnographers, things contribute a different perspective and unique insights on human practices that enhance, complicate, and perhaps even challenge those of human ethnographers.

\section{Rethinking practice from a material objects' perspective}

By suggesting an ontological symmetry between people and things, where objects too form networks, communicate, and even perform tasks (Kuijer \& Giaccardi 2015), Thing Tank troubles distinctions between subjects and objects (Law 1991), and between ideality and materiality (Engeström \& Blackler, 2005). These ontological reworkings are especially relevant for the emerging field of networked objects that 
belong to the Internet of Things, since these objects acquire perspective and agency through the data they collect, the stories they reveal, and the interventions they make in the lives of the people that use them (e.g., McVeigh- Schultz et al. 2012). But because the focus of IoT research has, to date, been exclusively human-centered, so that designed products and services are meant to answer the needs of people only, little attention has been given to how objects and their users are engaged in a 'dialogue' of mutual interaction that might produce new relationships and value. These were the themes that inspired the Thing Tank project.

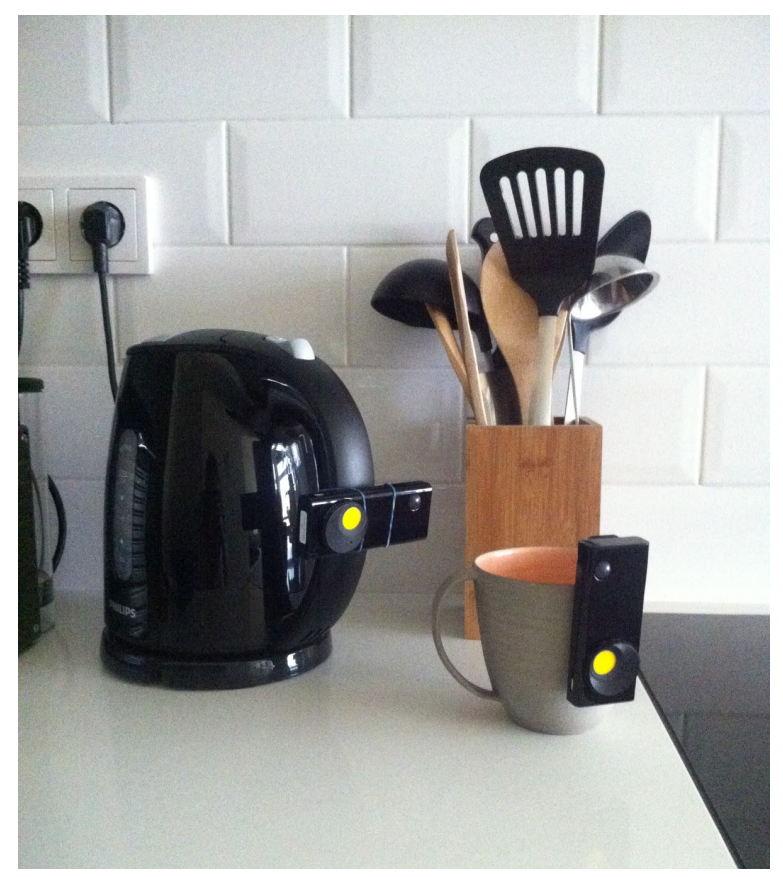

Figure 1: Autographers attached to a kettle and cup.

Focusing on everyday home practices, the Thing Tank pilot study selected three mundane objects: a kettle, a fridge, and a cup. Because these objects are often in proximity, it was thought that together they would reveal insights not just about themselves but also about their relationships with each other - that is, about unexpected horizontal arrangements of various practices. Data were collected through interviews and information gathered by intelligent cameras (Autographers) that were attached to three key material objects in the home (kettle, cup, and refrigerator), as well as to four individuals who participated in home-based activities (Figure 1).

Data collected from the Autographers (small cameras equipped with sensors and worn on a neck strap or clipped to an object) provided detailed information about 
the use patterns of particular objects and their trajectories throughout space and time, as well as data on parallel activities and objects. What was especially important was that the Autographers were intended to capture the experiences of objects from the perspective of those objects. As a form of "intelligent" technology, Autographers automatically take pictures and capture data via five sensors (e.g., accelerometer to determine movement, color sensor, magnetometer, thermometer, and PIR proximity sensor). Autographers lack shutter buttons, and photographs are taken automatically by the camera, rather than according to deliberate choices or intervention by the photographer. As such, these images were not positioned from the perspective of the researcher and instead captured events and vantage points that might have evaded the researcher. The Autographers collected $3000+$ photographs, which were then combined in a timeline (Figure 2).

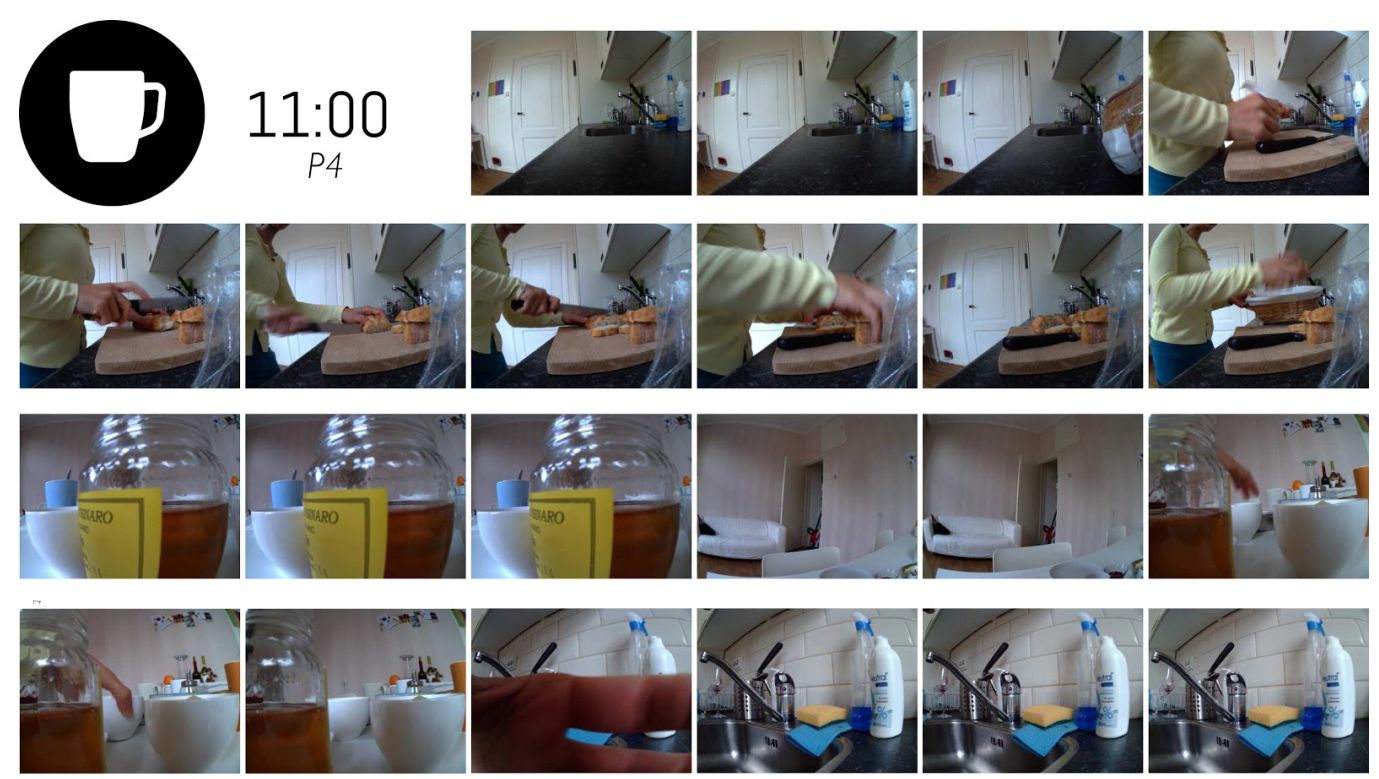

Figure 2: Format of the photographs taken by Autographers (from a cup's perspective).

Whereas in-depth interviews conducted with the four participants documented how they described and subjectively valued their activities, Autographer data revealed additional objects that were related to those activities, besides the key objects initially selected: other dishes, silverware, towels, papers, and pet food, among many other things. Autographers data illuminated unexpected and otherwise invisible relationships among objects - that is, the bundles or ecosystems inhabited 
horizontally by objects. Such data about the wider ecosystems of objects and practices are productive for creating a topographic landscape of the environment in which objects as 'things' reside and the relationalities that exist among these things and their "worlds" - a perspective that would have been difficult to elicit through traditional observations and interviews alone.

\section{Insights about the implications of a thing perspective}

The pilot study revealed a number of intriguing insights, both about the implications of a thing perspective and about the methods used to capture this approach. For instance, the preliminary data provided details for mapping out the landscapes that are occupied by things and the ways in which things - and the three key objects in particular (kettle, fridge, and cup) - inhabit and move through those spaces. As the data showed, the things that inhabited our participants' kitchens and dining rooms demonstrated different degrees of dynamism and emplacement. There are differences between things that move and those that stay in one place or remain within a narrowly defined area of space. Over the course of an ordinary day, numerous things moved into and out of the spaces under observation: cups, fresh produce, plastic bags, cutlery, kitchen towels, particular items of clothing. Things traveled with participants from their kitchens and into other home spaces (dining rooms, bedrooms) and then out of their homes into cars and on to work. These travels brought things into contact with other things - cars, radios, telephones, computers, books, papers, cigarettes, among others - and even into other settings such as kitchens in workplaces. As a result, these things moved through networks of spaces, times, and relationships, thereby not only occupying multiple ecosystems but also being the connector among these ecosystems.

Yet not all things move. As the data also revealed, some things remained in place, or within a confined area: refrigerators, kettles that were plugged into walls, sinks, and food items remained within a narrow band of movement. While this lack of movement suggests stasis, that is only a spatial stasis as those same objects are subject to movement through time. There is thus a paradoxical quality to things: while they may be "substances-in-becoming" filled with potentialities (Ingold 2013: 31), they are also entities with distinct life cycles and potential finalities, even as those post-use 
phases may have life cycles of their own (Evans et al. 2013). A simple teacup is simultaneously a thing with a predefined use that is actualized in a moment of praxis (i.e., when it is used as a vessel for tea or another beverage) and a thing that has possibilities for other practices and futures beyond those for which it was intended, such as when it is turned into a pencil cup, measuring cup, or a prop to hold open a window. Or even when, like in the case of one of our participants, the cup is carried around for companionship, like a pet. At the same time, as a teacup moves through its own unique lifecycle, its nature, identity, and value may change: from useful object to waste to recycled object and so on. Thus paying attention to movement illuminates distinctions between things that are located and things that are locational. They exist in relationships with one another, but they also inhabit separate, albeit occasionally overlapping, communities of things and practices, a distinction that invites questions about the boundaries and internal dimensions of things, ecosystems and the webs of relationality in which they are embedded.

The spatial parameters of the communities in which these things exist and circulate are further defined by temporal dimensions. While the things under view in the pilot study can be located in discrete temporal moments - for instance, the particular moments in which their existence and movements are captured discursively, visually, or with other sensors - these things also enjoy their own, unique temporal rhythms. For instance, while a cup, kettle, refrigerator, boiling water, coffee, and sugar may exist at the same moment, they are moving through time in different ways, such that the cup warms up, the boiling water cools down, and the coffee and sugar become transformed into different states. In addition, even as they interact with one another, at the same time, individual things do not have the same experience of time. A revealing finding was that while people were waiting for water to boil in the kettle and for their tea or coffee to be ready, they engaged in other activities: washing dishes, reading the paper, making a telephone call (Figure 3). Hence even as things occupy time and take up time, they also make time. In some cases, things fill time, and in other cases they create empty time that needs to be filled by others, as with participants finding other tasks to complete while they waited. 


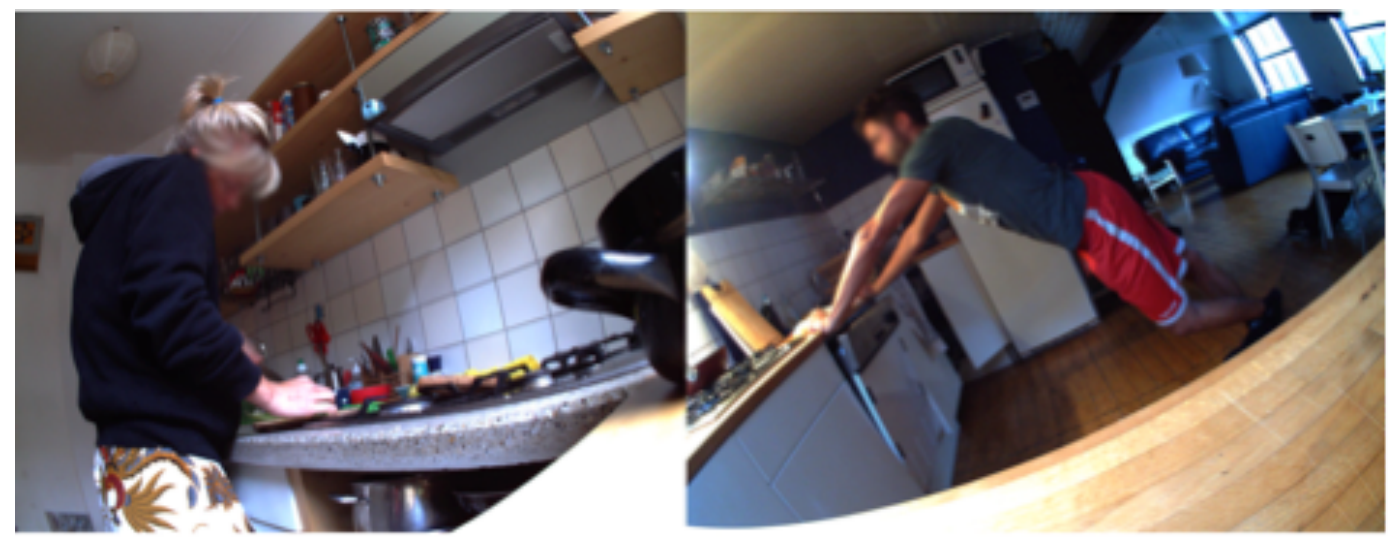

Figure 3: Things done while waiting for the water to boil (from a kettle's perspective).

More than providing evidence of contemporary practices of simultaneity, or multitasking, the different temporalities that unite and separate things from one another and from their human partners, present opportunities to consider what it is about the nature of things that enables them to create particular temporalities or make particular temporalities apparent or even visible. More generally, the effects of things' influence on time raise questions about the nature of filled time versus empty time. Paying attention to the ways in which both people and things create, fill, and experience time in very different ways offers new insights for thinking about the extent to which temporal structures are products of human activity or may exist outside an exclusively human-centric framework (cf. Munn 1992). Similarly, although "empty" time might feel like anxiety, boredom, or another affective response from the perspective of a person (see Löfgren and Ehn 2010), considering the experience of time from the perspective of an inanimate thing troubles phenomenological approaches centered on the human only. A thing perspective to time invites us to reconsider the relationships between human and non-human partners and how each provokes the other to respond to these relationships. When participants elect to read a book or wash dishes while they are waiting for their tea to steep, it seems as if it is the inanimate thing that is controlling the relationship and compelling the human to respond.

Ultimately these are concerns with the nature of agency within things (cf. Barad 2003; Bennett 2010; Latour 1988, 1992; Murphy 2013). If we take seriously the idea that things are actants, an idea that is supported by preliminary data from this 
pilot study, this shifts our understandings of how things move through time and space. While things may be mobile in the sense that they can be moved as the consequence of action by another, either human or non-human, a thing perspective also reveals that things possess qualities of motility and can move on their own, thereby changing the states, spaces, and times of their own existence and of other entities with which they come into contact. As such, these qualities of motility and activity provoke intriguing questions about the nature of the agency that inheres in them. In these social relationships among things, where is power located? In a model of social action informed by a thing perspective, does power exist as a pulsing web of shifting relationalities (Foucault 1990), or is it a relationality of directed force and response (Gramsci 1994; Scott 1986)? Can agency be external, or is it always internal to the thing itself? And lastly, how do we need to rethink the troubling issue of motivation and desire that are presumed to inhere in human actions? How does a thing perspective to agency and effect open up spaces for rethinking not just how and where potentialities emerge, but whether there are dynamics of both spontaneity and purposefulness outside a subjective human experience?

Beyond these ethnographic and theoretical implications, the pilot study data also pointed to intriguing and challenging issues about the methods used to capture a thing perspective. For instance, Autographers were useful for capturing moments that were not mentioned by respondents during the interviews or diaries but were key moments in the daily routines of objects. Because many practices and encounters in everyday life are so mundane and taken for granted as to be unremarkable and invisible (Rosaldo 1993), they are often outside the scope of awareness of participants. Yet things that are unremarkable are actually made so through a "politics of mereness" (Herzfeld 2005: 132) that disguises their meaningfulness within multiple relationalities and practices (Rosaldo 1993). Nothingness is, however, full of something (Löfgren and Ehn 2010; Ritzer 2003). Because Autographers automatically take pictures without input from the photographer, and are thus presumed to be outside the cultural values and perspectives of the observer, they capture images that might otherwise seem unremarkable and unmeaningful to a researcher or the participant. Thus, they are crucial for filling in the gaps and revealing to humans unexpected meaningful moments. A good example of these unmarked moments came in the series of photographs that showed participants engaged in multiple activities 
simultaneously (e.g., talking on the phone while preparing food), a detail that was not captured in the interviews.

While specific details about the significance of these activities and cooccurrence of these events are not available, Autographer data revealed events that were not expected and could be investigated further. In other instances, the Autographer data revealed contradictions between participants' self-reporting in interviews and diaries and the captured images, such as in a case in which a participant did not identify any other residents in the home yet the pictures showed pet food. In another case, the respondent framed answers only in terms of a single person, but images showed her interacting with another person and sharing a meal with that other person. Thus there were multiple persons and multiple things interacting simultaneously that were not otherwise documented and had been downplayed or forgotten by the participant.

Such types of data captured, in this case, by photographic equipment that is not dependent on the choices made by the photographer raise intriguing questions for visual anthropology, design anthropology, and other fields both about when and where "meaningful" events and practices occur and the role of humans and nonhuman things in demarcating social worlds and the relationships within those worlds. ${ }^{\text {vi }}$ A thing perspective opens up possibilities for understanding the limits of human action on time and space and the ways in which non-human things are directly informing and creating the everyday realities in which people live. For both anthropology and design, these are concerns that are simultaneously methodological, theoretical, ethnographic, and even ethical.

\section{Considering things as co-ethnographers}

According to Binder et al. (2011), the creation of a design space is the creation of a 'field work' that does not exist but it is possible. Intended as a possibility, this speculative space emerges out of the ongoing interaction among participants in design. The Thing Tank pilot study suggests that things may have access to fields, data and 'perspectives' that we as humans do not. Considering things as coethnographers present additional opportunities for design anthropological approaches 
concerned with opening up perspectives on the emergent (Smith \& Otto, this volume), as things can help us 'see' what is not immediately apparent in human practices.

Of particular concern to anthropology is the use of ethnographic approaches to investigate the motivations, beliefs, and values that inform people's practices and the objects they use in these practices, especially in terms of understanding discrepancies between reported and actual practice. The forte of ethnography is contextualization, holistic explanation, and cultural interpretation through cross-cultural comparison and the development of theoretical concepts (Otto \& Smith 2013). Data gathered through ethnographic research can help identify gaps and contradictions, and ultimately initiate critical inquiry into issues of generality and specificity, routine patterns and deviations from norms. However, as advocated by Kjærsgaard \& Otto: "the role of fieldwork and anthropology within design cannot simply be to provide designers with descriptions of users and use practices as in the tradition of ethnomethodologically informed design; nor can it simply be to supply methods and techniques for enrolling users and their knowledge directly within the design process as in the tradition of participatory design" (Kjœrsgaard \& Otto 2012: 179).

A thing perspective challenges anthropocentric assumptions about the world and open up new ways of understanding objects, people and use practices. Paying attention to the immanent dynamism inherent in things invites intriguing questions about how objects, practices, and other things exist in the world and the qualities of their agentive capacities. Like humans, objects, practices and things never exist in a vacuum but are always situated in particular temporal and spatial contexts. As such, things themselves are positional and relational, and their uses, values, and meanings may change significantly from context to context (Appadurai 1986; Hermann 1997; Kopytoff 1988). On the other hand, objects, practices and things may themselves have their own temporal and spatial systems and rhythms that, in turn, affect and shape other elements in the world around them (Bachelard 1994; Amato 2013). Things are thoroughly imbricated within ecosystems that are populated by other things, both human and non-human, and both human-produced and non-human-produced. These insights about the mutually constituting life-worlds of things are helpful for thinking through the preliminary data from our pilot study, especially as possibilities for making sense of different perspectives about the nature and positionality of things. 
Attributing agency to objects is not a new concept. Actor network theorists discuss the ontological symmetry of humans and nonhumans, in which material forms take on the characteristics of humans: they judge, form networks, speak, and work performatively (Engeström \& Blackler, 2005). Developmental psychology has demonstrated that people ascribe intentionality and consciousness to inanimate things (Piaget, 1959), and the psychodynamic tradition in psychoanalysis points out striking similarities in how people relate to the animate and the inanimate (Turkle, 2011). More recently, object-oriented philosophy posits that things do not exist just for us (Bogost 2012). They can be many and various (Bryant, 2011), but no matter their size, scale, or order, they enjoy equal being (Harman, 2009). And certainly anthropologists concerned with materialities have suggested that objects are dynamic and emergent entities that contain their own life forces, energies, and histories (e.g., Appadurai 1986; Ingold 2013; Mauss 1990).

A thing perspective offers design nuanced ways of thinking about and intervening into agency and social arrangements, most notably those between producer and produced, and between subject and object, such that there is an understanding that these are never fully discrete roles or nodes but rather emergent states of being (Anusas and Ingold 2013). Enlisting things as co-ethnographers provides unique insights about the temporality, movement, and relationships of objects, and thus a new perspective to think about human practice. Imagining the time perception of objects (e.g., what would empty or filled time look like from the perspective of an inanimate thing? what are the multiple routines and rhythms that exist among and across the things that are in relationships with one another?) or speculating about how their social dynamics (e.g., how does the nature of the relationships change when an object moves among different users or the same user moves among different objects from the same category?) can bring novel insights about the role of objects in human practices, and thus open up design opportunities that we may not be able to foresee with traditional methods of user research. ${ }^{\text {vii }}$

In the 'designerly' tradition (Cross 2007), a thing perspective aims to offer a possible, arguably more desirable design alternative that is based on a fundamentally different relationship between humans and non-humans. In particular, it harbours different ideas about expertise and skills and redistributes ideation, design and control between professional design and everyday use practices. The patterns revealed 
through a thing perspective about human practices emerge at the intersection of the data and trajectories that things give access to and the theoretically informed analysis that humans bring to it. This is not done simply to provide anthropologists with different and unique information about use practices, or to offer designers inspiration for creative solutions. The aim of a thing perspective is fundamentally to enable the exploration of practices and objects of design that are not constituted yet but emerge in response to non-human ethnographies, or rather 'correspond' (Gatt \& Ingold 2013) to their ongoing analysis.

For design anthropology, a thing perspective does not just expose and describe forms of practice that is difficult to express in terms of just design or use, but it reveals "kinds of things" and "states of being" as well (Redström 2012: 95). As opposed to a human-centered perspective, a thing perspective brings unique insights about the relationships among objects and human practices, and ultimately presents new ways of framing and solving problems collaboratively with 'things', which have different skills and purposes than humans.

\section{Acknowledgements}

The authors would like to thank Neil Rubens and Fionn Tynan-O'Mahony for their invaluable contributions to Thing Tank. Sincere gratitude also goes to the editors and to the reviewers of this text for helping the authors crafting this contribution with tireless dedication. The Thing Tank project was originally funded by the MIT Skoltech Initiative (2014-2015).

\section{References}

1. Amato, J. A. (2013), Surfaces: A History, Berkeley: University of California Press.

2. Anusas, M. \& Ingold, T. (2013) 'Designing Environmental Relations: From Opacity to Textility', Design Issues, 29 (4), 58-69.

3. Appadurai, A. (1986), 'Introduction: Commodities and the Politics of Value', in A. Appadurai, (ed.), The Social Life of Things: Commodities in Cultural Perspective, 3-63, Cambridge: Cambridge University Press. 
4. Ashton, K. (2009), 'That "Internet of Things" thing', RFID Journal: 22 June, http://www. rfidjournal.com/article/view/4986 (accessed 4 December 2011).

5. Bachelard, G. (1994), The Poetics of Space, Beacon Press.

6. Barad, K. (2013) 'Posthumanist Performativity: Toward an Understanding of How Matter Comes to Matter', Signs: Journal of Women in Culture and Society, 28, 801-831.

7. Bennett, J. (2010), Vibrant Matter: A Political Ecology of Things. Durham, NC: Duke University Press.

8. Binder, T., De Michelis, G., Ehn, P., Jacucci, G., Linde, P., Wagner, I. (2011), Design Things, Cambridge, MA: MIT Press.

9. Bogost, I. (2012), Alien Phenomenology, or, What It's Like to Be a Thing, Minneapolis, MN: University of Minnesota Press.

10. Cila, N., Giaccardi, E., Caldwell, M., Tynan-O’Mahony, F., Speed, C., Rubens, N. (2015a), 'Listening to an Everyday Kettle: How Can the Data Objects Collect Be Useful for Design Research?', in Proceedings of the 4th Participatory Innovation Conference 2015 (PIN-C2015), The Hague, Netherlands: The Hague University of Applied Sciences, 500-506.

11. Cila, N., Giaccardi, E., Tynan-O’Mahony, F., Speed, C., Caldwell, M. (2015b), 'Thing-Centered Narratives: A Study of Object Personas', in Proceedings 3rd Seminar of the Research Network for Design Anthropology, January 22-23, 2015, Aarhus, Denmark .

12. Cross, N. (2007). Designerly Ways of Knowing. Basel: Birkhäuser.

13. Donovan, J. and Gunn, W. (2012), 'Moving from Objects to Possibilities', in W. Gunn \& J. Donovan (eds) Design Anthropology, Farnham, UK: Ashgate Publishing Company.

14. Ehn, P. (2008), 'Participation in Design Things', in Proceedings of the Tenth Anniversary Conference on Participatory Design 2008 (PDC '08), 92-101.

15. Engeström, Y. and Blackler, F. (2005), 'On the Life of the Object', Organization, 12 (3): 307-30. 
16. Evans, D., Campbell, H., Murcott, A. (eds) (2013), Waste Matters: New Perspectives on Food and Society, Malden, MA: Wiley-Blackwell/The Sociological Review.

17. Foucault, M. (1990), The History of Sexuality, New York: Vintage Books.

18. Gatt, C. \& Ingold, T. (2013), 'From Description to Correspondence:

Anthropology in Real Time,' in Gunn, W., Otto, T. \& Smith, R.C. (eds.), Design Anthropology: Theory and Practice. Bloomsbury, 139-158.

19. Giaccardi, E. (2005), Metadesign as an Emergent Design Culture, Leonardo, 8 (4): $342-49$

20. Giaccardi, E. and Fischer, G. (2008) 'Creativity and Evolution: A Metadesign Perspective', Digital Creativity, 19 (1), 19-32.

21. Gramsci, A. (1994), Letters from Prison, New York: Columbia University Press.

22. Greenbaum, J. and Kyng, M. (1991), Design at Work: Cooperative Design of Computer Systems, Hillsdale, NJ: L. Erlbaum Associates.

23. Gunn, W. and Donovan, J. (2012), 'Design Anthropology: An Introduction', in W. Gunn and J. Donovan (eds), Design Anthropology, Farnham, UK: Ashgate Publishing Company.

24. Harman, G. (2009), Prince of Networks: Bruno Latour and Metaphysics, Re.press.

25. Herzfeld, M. (2005), Cultural Poetics: Social Intimacy in the Nation-State, New York: Routledge.

26. Ingold, T. (2013), Making: Anthropology, Archaeology, Art and Architecture, London: Routledge.

27. Kjœrsgaard, M. and Otto, T. (2012), Anthropological Framework and Design Potentials, in W. Gunn and J. Donovan (eds), Design Anthropology, Farnham, UK: Ashgate Publishing Company.

28. Kopytoff, I. (1986), 'The Cultural Biography of Things: Commoditization as Process', in A. Appadurai (ed.), The Social Life of Things: Commodities in Cultural Perspective, 64-91, Cambridge: Cambridge University Press. 
29. Kuijer, L. \& Giaccardi, E. (2015), 'Considering Artifacts as Co-performers', in Symposium on Animals, Automated Devices and Ecosystems: Dynamic Non-humans in Theories of Social Practice, 9-10 October, Barcelona, Spain.

30. Latour, B. (1992), 'Where are the Missing Masses? The Sociology of a Few Mundane Artifacts', In W. Bijker and J. Law (eds.) Shaping

Technology/Building Society: Studies in Sociotechnical Change, 225-228, Cambridge, MA: MIT Press.

31. Latour, B. (1988), Science in Actin: How to Follow Scientists and Engineers through Society, Cambridge, MA: Harvard University Press.

32. Law, J. (1991), 'Introduction: Monsters, machines and sociotechnical relations', in J. Law (ed.), A Sociology of Monsters: Essays on Power, Technology and Domination, London: Routledge.

33. Löfgren, O. and Ehn, B. (2010), The Secret World of Doing Nothing, Berkeley: University of California Press.

34. Mauss, M. (1990), The Gift: The Form and Reason for Exchange in Archaic Societies, London: Routledge.

35. McVeigh-Schultz, J., Stein, J., Watson, J., Fisher, S. (2012), 'Extending the Lifelog to Non-human Subjects: Ambient Storytelling for Human-Object Relationships', Proceedings of the 20th ACM international conference on Multimedia, 1205-08, New York: ACM Press.

36. Munn, N. D. (1992), 'The Cultural Anthropology of Time: A Critical Essay', Annual Review of Anthropology, 21, 93-123.

37. Murphy, K. M. (2013), 'A Cultural Geometry: Designing Political Things in Sweden', American Ethnologist, 40 (1), 118-131.

38. Otto, T. and Smith, R. C. (2013), 'Design Anthropology: A Distinct Style of Knowing', in W. Gunn, T. Otto and R. C. Smith (eds), Design Anthropology: Theory and Practice, 1-29, London: Bloomsbury Academic.

39. Piaget, J. (1959), The Language and Thought of the Child, London: Routledge \& Kegan Paul.

40. Redström, J. (2012), 'Introduction: Defining Moments', in W. Gunn and J. Donovan (eds), Design Anthropology, Farnham, UK: Ashgate Publishing Company. 
41. Ritzer, G. (2003), The Globalization of Nothing, Thousand Oaks, CA: Pine Forge Press.

42. Rosaldo, R. (1993), Culture \& Truth: The Remaking of Social Analysis, Boston: Beacon Press.

43. Schuler, D. and Namioka, A. (1993), Participatory Design: Principles and Practices, Hillsdale, NJ: L. Erlbaum Associates.

44. Scott, J. C. (1986), Weapons of the Weak: Everyday Forms of Peasant Resistance, New Haven, CT: Yale University Press.

45. Smith, R.C. \& Otto, T. 'Scaffolding Possible Futures: Emergence and Intervention in Design Anthropology', this volume.

46. Turkle, S. (ed.) (2011), Evocative Objects: Things We Think With, Cambridge, MA: MIT Press.

${ }^{\mathrm{i}} \mathrm{Cf}$. also the ISO standard Human-centred design for interactive systems (ISO 9241210, 2010): http://www.iso.org/iso/catalogue_detail.htm?csnumber=52075.

ii In this text, we use the term 'object' as a synonym for material artifact. We use instead the term 'thing' to emphasize the situated relationships of the object with other entities and its potential to influence the existence of those other entities. In that sense, equipped with software and sensors and connected to online databases, a fridge for example is unavoidably a 'thing': not just an object in its straight materiality, but a gathering of data, connections and interactions.

iii The phrase Internet of Things is attributed to the Auto-ID research group at MIT in 1999 (Ashton 2009) and refers to the emerging technical system of objects and materials that are becoming connected to the Internet. The specific reference to 'things' refers to the principle that physical objects will be part of this extended Internet, each with its own associated data cloud concerning where the object has been and how it has been used.

iv Thing Tank (http://www.thingtank.org/) operates as an international research platform coordinated by Delft University of Technology in collaboration with the Centre for Design Informatics, University of Edinburgh. The project was originally funded by the MIT Skoltech Initiative (2014-2015).

${ }^{\mathrm{v}}$ The approach also requires sensitivity to the role of machine learning. The discussion, however, is behind the scope of this chapter. For insights on the integration of ethnographic data and machine learning data, see Cila et al. (2015a).

${ }^{\text {vi }}$ A further layer to the Thing Tank study that extends the ability to capture data that is not dependent upon a human, is the quantitative data that is captured through the sensors that record the use of the kettle, cup and fridge. Although the study did not go 
into depth using Machine Learning (ML) to interrogate the quantitative data captured from the accelerometers, magnetometers and proximity sensors these, the use of ML offers a further method of enquiry with which to identify patterns that are beyond the 'vision' of the human.

vii See Cila et al. $2015 \mathrm{~b}$ on the development of thing-centred design methods such as "thing-centred narratives" and "object personas". 